\title{
Detrital provenance of the Upper Triassic siliciclastic rocks from southwest Iberia: a review
}

\author{
M. Francisco Pereira ${ }^{1} \cdot$ Cristina Gama ${ }^{2}$
}

Received: 22 March 2017 / Accepted: 27 May 2017/Published online: 5 June 2017

(C) Springer International Publishing Switzerland 2017

\begin{abstract}
Background In southwestern Iberia the Upper Triassic successions of Lusitanian, Alentejo and Algarve basins records the fragmentation of Pangaea in Permian-Triassic during which the paleogeography of Iberia was dominated by a series of coalescing, alluvial-deltaic wedges and axial braided rivers.

Purpose In this study, we discuss the potential sediment sources of the Lusitanian, Alentejo and Algarve basins based on detrital zircon-age spectra, suggesting that Iberia occupied a central position Iberia in Pangaea during late Triassic.

Methods Conventional sedimentary petrography and paleocurrent measurements of previous works was combined with recently published detrital zircon $\mathrm{U}-\mathrm{Pb}$ geochronology of the Upper Triassic siliciclastic rocks of southwest Iberia to shed light on the detrital provenance record.

Results Zircon age populations found in the Upper Triassic strata of the Lusitanian, Alentejo and Algarve basins is dominated by Neoproterozoic (33-76\%) and Paleoproterozoic (12-15\%) grains. The most important differences are the dominance of Devonian-Carboniferous (33\%)
\end{abstract}

This review paper contributes to better understand the generation and evolution of the southwest Iberia Upper Triassic basins and to refine the paleogeographic reconstruction of Pangaea just before the opening of the Central Atlantic Ocean.

M. Francisco Pereira

mpereira@uevora.pt

1 IDL, Departamento de Geociências, Escola de Ciências e Tecnologia, Universidade de Évora, Évora, Portugal

2 ICT, Departamento de Geociências, Escola de Ciências e Tecnologia, Universidade de Évora, Évora, Portugal zircon in the Alentejo basin and the greater representativeness of Permian-Carboniferous (6\%) zircon in the Lusitanian basin.

Conclusion The deposition in these Upper Triassic basins of Portugal is marked by variability in sedimentary sources, involving the denudation and local-scale directions of sediment transport from the Iberian basement with possible additional supplies derived from outside present-day Iberia. The Upper Triassic successions evolved separately with the detrital transport being probably controlled by local drainage systems, and occupying a central position in Pangaea just before the opening of the Central Atlantic Ocean.

Keywords Upper Triassic continental basins .

Sedimentary sources · U-Pb zircon geochronology ·

Pangaea $\cdot$ Iberia

Resúmen En esta revisión, combinamos la petrografía sedimentaria convencional y las mediciones de paleocorrentes obtenidas de trabajos previos de las rocas sedimentarias siliciclásticas del Triásico Superior del suroeste de Iberia, con datos de geocronología U-Pb de circón detrítico recientemente publicados por nosotros. El objetivo del trabajo es mejorar el conocimiento sobre la procedencia de las rocas sedimentarias siliciclásticas del Triásico Superior de las cuencas Lusitaniana, del Alentejo e del Algarve. En las poblaciones de circón detrítico de las cuencas del Triásico Superior del suroeste de Iberia predominan las edades del Neoproterozóico (33-76\%) y Paleoproterozóico (12-15\%). Las diferencias más importantes son: el predominio de granos del Devónico-Carbonífero (33\%) en la cuenca del Alentejo y la mayor representatividad de granos del Permiano-Carbonífero (6\%) en la cuenca Lusitaniana. La deposición en estas cuencas del Triásico Superior de Portugal se caracteriza por la variabilidad de las fuentes 